\title{
Field guide to the Jurassic Otlaltepec and Tezoatlán Basins, southern Mexico: sedimentological and paleontological records of Puebla and Oaxaca
}

\author{
Michelangelo Martini, Patricia Velasco-de León, Mildred Zepeda-Martínez, \\ Diego E. Lozano-Garmona, Mónica Ramírez-Calderón
}

\begin{abstract}
Michelangelo Martini
mmartini@geologia.unam.mx

Instituto de Geología, Universidad Nacional Autónoma de México, CDMX, 04510, México.
\end{abstract}

\section{Patricia Velasco-de León} Diego E. Lozano-Garmona

Facultad de Estudios Superiores Zaragoza, Universidad Nacional Autónoma de México, CDMX, 09230, México.

\section{Mildred Zepeda-Martínez} Mónica Ramírez-Calderón Posgrado en Ciencias de la Tierra, Universidad Nacional Autónoma de México, CDMX, 04510, México.
BOL. SOC. GEOL. MEX. 2017

VOL. 69 NO. 3

P. $691-709$

\begin{abstract}
By early Mesozoic time, a major plate reorganization produced the breakup of Pangea, which was the most recent supercontinent assembled on Earth. Due to its paleogeographic position along the emergent plate boundary between North and South America, the early Mesozoic tectonic history of Mexico was dominated by the development of major normal to strike-slip faults. These faults produced a complex crustal configuration characterized by subsiding basins bounded by exhuming basement highs. Voluminous, continental to marine sedimentary successions were accumulated into these basins during the Jurassic, representing a unique stratigraphic record related to the fragmentation of the western equatorial margin of this supercontinental mass.

This field trip will provide an overview of the Otlaltepec and Tezoatlán Jurassic Basins that are exposed in the states of Puebla and Oaxaca, southern Mexico. Observed outcrops are exposed along two amazing canyons and consist of alluvial-fluvial to marine clastic deposits. Major provenance changes are recorded in the Jurassic successions of the Otlaltepec and Tezoatlán Basins and are interpreted as the result of exhumation of different fault-bounded lithospheric blocks during Pangea breakup. The integration of petrological and paleontological data indicates that these major changes in provenance of clastic rocks match with changes in climatic conditions. Therefore, in this field trip, we will have the opportunity to explore the hypothesis that the progressive exhumation of lithospheric blocks during the fragmentation of Pangea could have produced major topographic changes that favored local variations in climatic conditions and consequently, the diversification of floral assemblages in Mexico.
\end{abstract}

Keywords: Pangea breakup, intra-continental rift basin, southern Mexico, Jurassic flora.

\section{RESUMEN}

A partir del inicio del Mesozoico, una reorganización de las placas tectónicas a escala global determinó la fragmentación de Pangea, la cual fue el supercontinente más reciente que se ensambló en la Tierra. Durante este evento tectónico global, el territorio mexicano ocupaba una posición de particular interés, ya que se encontraba en el límite de placa entre Norte y Sur América. Debido a dicha posición paleogeográfica, la evolución geológica de México durante el Mesozoico temprano fue controlada por la actividad de fallas normales y laterales, que determinaron una configuración cortical compleja y caracterizada por numerosas cuencas subsidentes bordeadas por altos de basamento en exhumación. Durante el Furásico, las cuencas generadas por este evento tectónico fueron los sitios de depósito de potentes sucesiones continentales a marinas, las cuales representan un registro estratigráfico único de la fragmentación de la Pangea en su margen occidental-ecuatorial.

Durante esta excursión, los participantes visitarán las cuencas jurásicas de Otlaltepec y Tezoatlán, las cuales están expuestas en los estados de Puebla y Oaxaca, al sur de México. Las dos barrancas que se visitarán contienen afloramientos bien expuestos de sucesiones clásticas aluviales-fluviales y marinas. Las sucesiones jurásicas de las Cuencas de Otlaltepec y Tezoatlán preservan claras evidencias de cambios en la procedencia de las rocas clásticas. Dichos cambios en la procedencia han sido interpretados como el resultado de la exhumación de diferentes bloques litosféricos a lo largo de fallas mayores durante el progresivo rompimiento de Pangea. La integración de los datos petrológicos y paleontológicos indica que estos cambios en la procedencia coinciden con cambios importantes en las condiciones climáticas. Por ende, se aprovecha la oportunidad de esta excursión para explorar la hipótesis que el proceso de exhumación de bloques litosféricos que acompañó el progresivo rompimiento de la Pangea pudo haber determinado una reorganización sustancial en la topografia, favoreciendo variaciones climáticas locales y, consecuentemente, la diversificación de la flora en México.

Palabras clave: fragmentación de Pangea, cuenca de rift intra-continental, sur de México, flora del Jurásico. 


\section{Introduction}

By the beginning of Mesozoic time, Precambrian and Paleozoic rocks that make up the backbone of present-day Mexico were located along the western margin of equatorial Pangea. The progressive fragmentation of the supercontinental mass during this time produced the development of normal to lateral, lithospheric-scale faults that accommodated the NW - SE regional extension imposed by North America-South America divergence (Pindell, 1985; Ross and Scotese, 1988; Dickinson and Lawton, 2001; Pindell and Kennan, 2009). These faults significantly shaped the Jurassic topography of Mexico, producing a complex crustal configuration characterized by progressively subsiding, extensional to transtensional basins bounded by basement highs (Morán-Zenteno et al., 1993; Goldhammer, 1999; Campos-Madrigal et al., 2013; Martini and Ortega-Gutiérrez, 2016). Considering that the atmospheric circulation in a certain geographic area is strongly influenced by the topographic configuration, the progressive exhumation of fault-bounded lithospheric blocks during Pangea breakup may have favored changes in climatic conditions in Mexico and, therefore, the diversification of floral assemblages.

This field trip will provide an overview of the Jurassic stratigraphic and fossiliferous records of the Otlaltepec and Tezoatlán Basins that are located in the states of Puebla and Oaxaca, southern Mexico (Figure 1). The observed outcrops are exposed along two canyons and consist of alluvial-fluvial to marine clastic deposits, which show major changes in composition that have been interpreted as the result of exhumation of different lithospheric blocks during the fragmentation of Pangea (e.g. Martini et al., 2016). The documented compositional changes in the Otlaltepec and Tezoatlán Basins match with major changes in climatic conditions, as it is suggested by sandstone petrologic data and fossil flora. We take the occasion of this field trip to synthesize the petrological and paleontological results obtained in the last decade by the authors of this field guide. This is with the aim of stimulating a constructive discussion on the control that the fragmentation of Pangea exerted on the climatic configuration and the paleofloristic evolution of Mexico and offering some perspective for future investigations.

\section{The Otlaltepec Basin}

The Otlaltepec Basin is exposed in the surroundings of Santo Tomás Otlaltepec (figures 1 and 2a) and is composed of a more than $2000 \mathrm{~m}$ thick clastic sedimentary succession. To the south-west, the clastic succession is faulted against the upper Paleozoic Totoltepec pluton (Kirsch et al., 2012) along the W-trending, sinistral normal Matanza fault (Figure 2a). The western boundary of the Otlaltepec Basin is represented by a NNE-trending normal fault along which the clastic succession is juxtaposed to Paleozoic metasedimentary rocks of the Acatlán Complex (Figure 2a; Ortega-Gutiérrez, 1978). The northern and eastern boundaries of the basin are not exposed. The comprehensive stratigraphic framework and internal architecture of the entire basin is poorly known because at present only its southern part has been exhaustively explored and studied. Along its southern part, the stratigraphic record of the Otlaltepec Basin has been subdivided into four units that, from the base to the top, are: the Tianguistengo, Piedra Hueca, Otlaltepec, and Magdalena Formations (Figure 2b; Ortega-Guerrero, 1989; Morán-Zenteno et al., 1993; Verde-Ramírez, 2016). These units are separated by regional-scale angular unconformities and are composed of fluvial to littoral deposits, some of which contain Jurassic flora (Ramos-Leal, 1989; Morán-Zenteno et al., 1993). This clastic succession is overlain by Lower Cretaceous shallow-marine limestones of the Coyotepec Formation, which were deposited during a regional-scale transgression event (Figure 2b; Morán-Zenteno et al., 1993).

During this field trip we will focus on the Piedra Hueca and Otlaltepec Formations. These units represent more than $80 \%$ in volume of the Ot- 


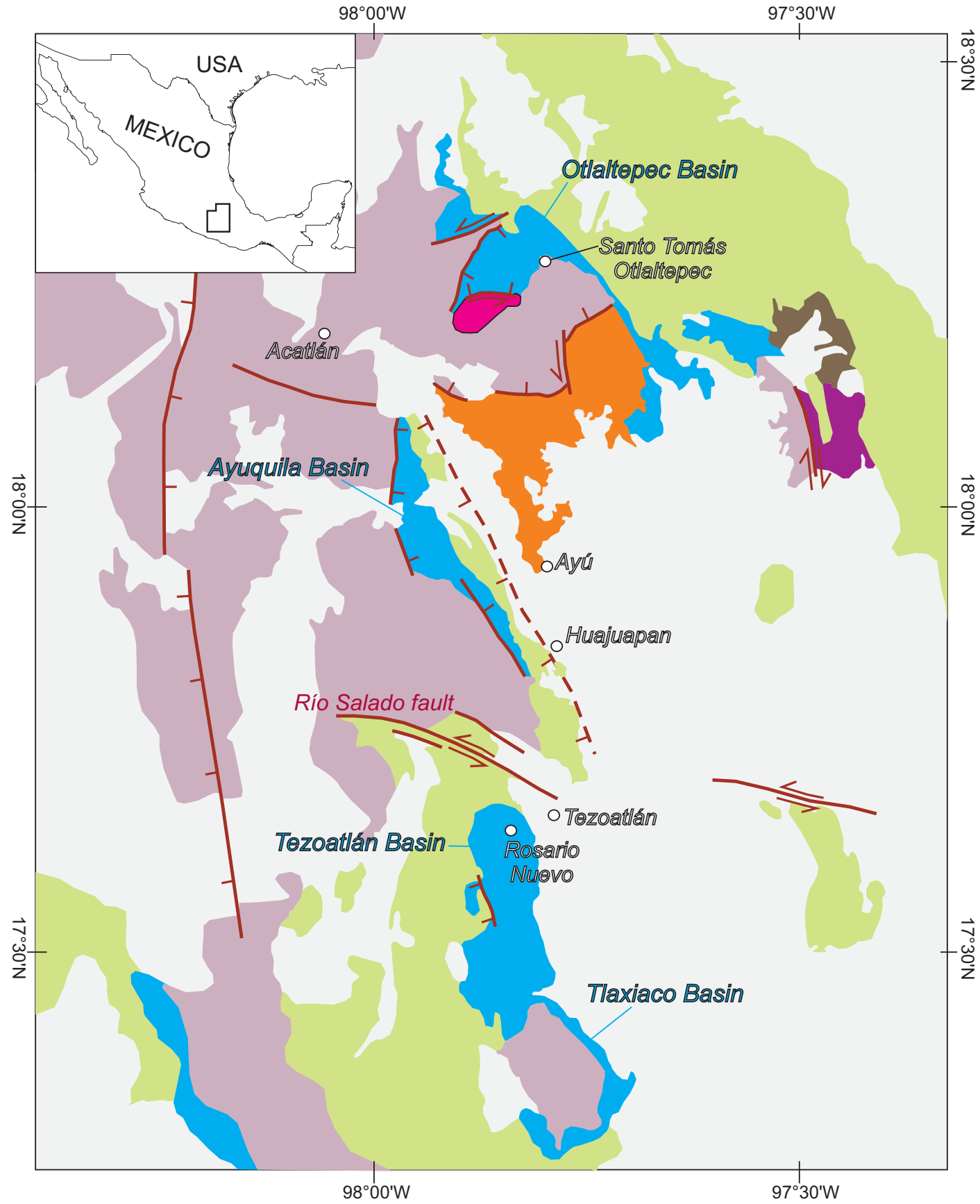

Undifferentiated Upper Cretaceous-Cenozoic successions Upper Jurassic-Lower Cretaceous carbonate successions Lower-Middle Jurassic, dominantly siliciclastic successions Upper Paleozoic Matzitzi Formation Upper Paleozoic Totoltepec pluton Paleozoic metamorphic rocks of the Acatlán Complex Grenvillian-age metamorphic rocks of the Oaxacan Complex Paleozoic metamorphic rocks of the Ayú Complex

\Major normal fault $\checkmark$. Inferred normal fault Major lateral fault

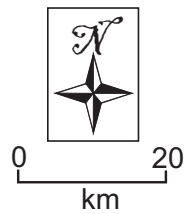

Figure 1 Geologic map of the southern Puebla and northern Oaxaca states, southern Mexico, showing the location and tectonic boundaries of major metamorphic and plutonic basement complexes, as well as the distribution of the Jurassic sedimentary successions (modified from Martini et al., 2016). 


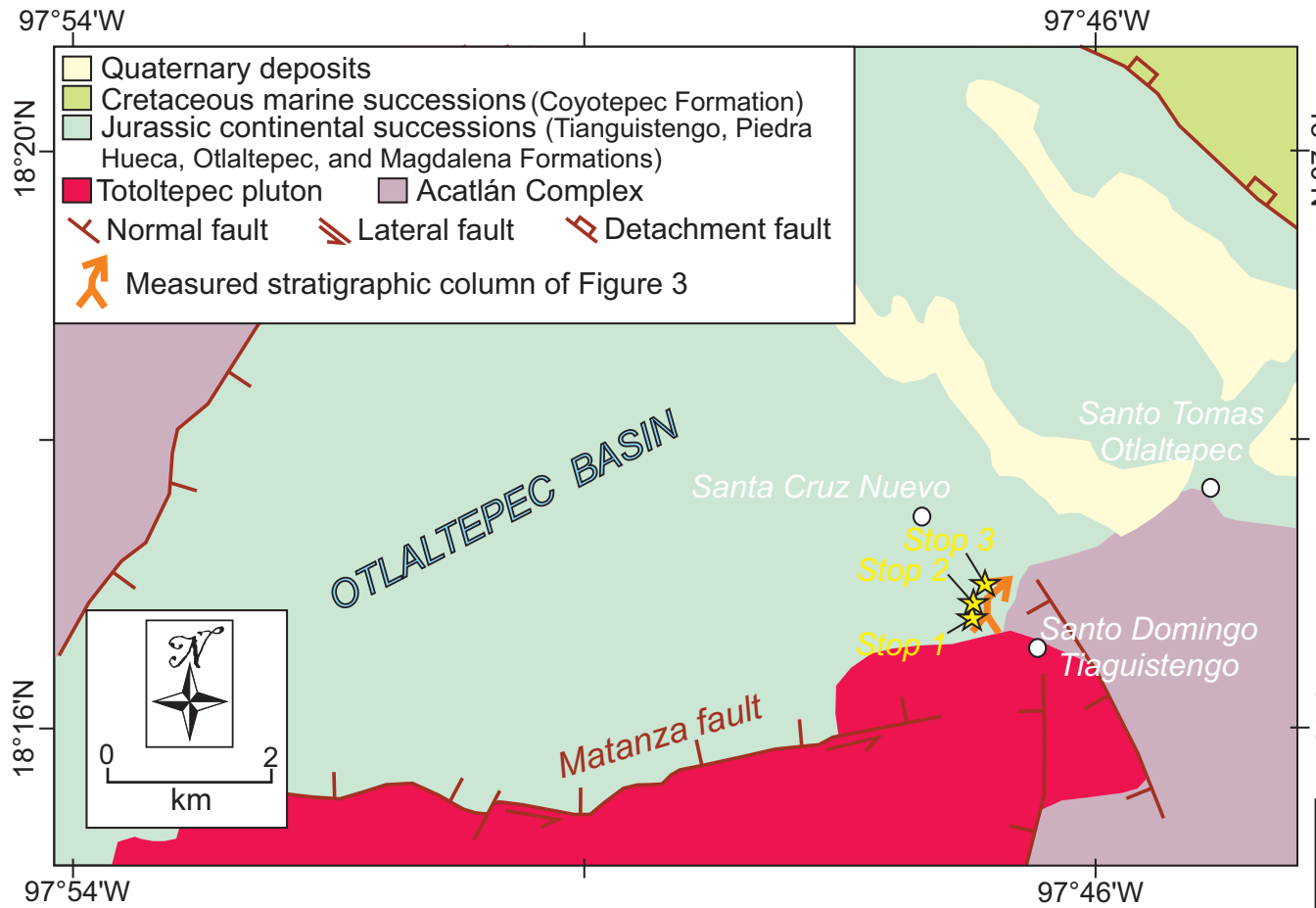

a

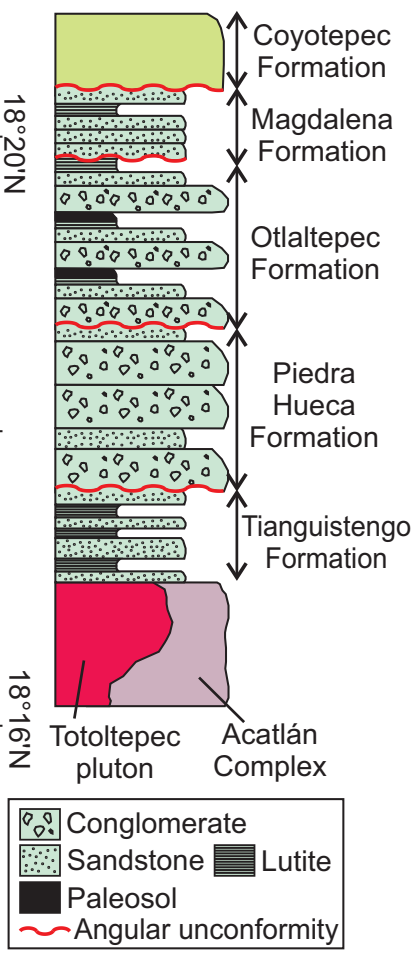

b

Figure 2 (a) Schematic geologic map of the Otlaltepec Basin, showing the distribution of the Jurassic continental succession and its contact relationship with basement rocks of the Acatlán Complex and Totoltepec pluton (modified from Martini et al., 2016). The location of the three main outcrops (yellow stars) that will be visited during the first day of the trip is reported in the map. (b) Schematic litostratigraphic column representative of the southern part of the Otlaltepec Basin. The column is according to MoránZenteno et al. (1993) and Verde-Ramírez (2016).

laltepec Basin and display a significant change in sandstone composition that has been interpreted as a manifestation of the complex history of extension and exhumation of lithospheric blocks during Pangea breakup (Martini et al., 2016).

\subsection{PIEDRA HUEGA FORMATION}

The Piedra Hueca Formation dominantly consists of superposed, meter- to decameter-thick, fining-upward fluvial successions that are composed from the base to the top of lithofacies Gt, Gp, St, and Sp (Table 1; Miall, 2006), eventually grading upward into lithofacies Sr and Fl (Figure 3; Martini et al., 2016). The superposition of these fining-upward successions records cyclical variations in the energy of the fluvial drainage. Gt and Gp lithofacies are interpreted as gravel bars deposited during high-water stages, and consist of scoopshape conglomeratic bodies. Both lithofacies cut laterally and vertically into each other (Figure 4a), reflecting a depositional setting dominated by unstable and laterally migrating channels (Martini et al., 2016). The overlaying St, Sp (Figure 4b), and $\mathrm{Sr}$ lithofacies are interpreted as the record of progressive decrease in energy of the fluvial flow, culminating with the deposition of suspended load represented by lithofacies Fl (Martini et al., 2016). Locally, matrix- to clast-supported, poorly-sorted, inversely-graded conglomerates of lithofacies Gci (Figure 4c) are interbedded with cross-bedded conglomerates. A sharp non-erosional base is typical of these massive conglomerates, suggesting that they were formed by high-strength debris flows (e.g. Miall, 2006). Additionally, centimeter- to decimeter-thick beds composed of tabular-shaped, 


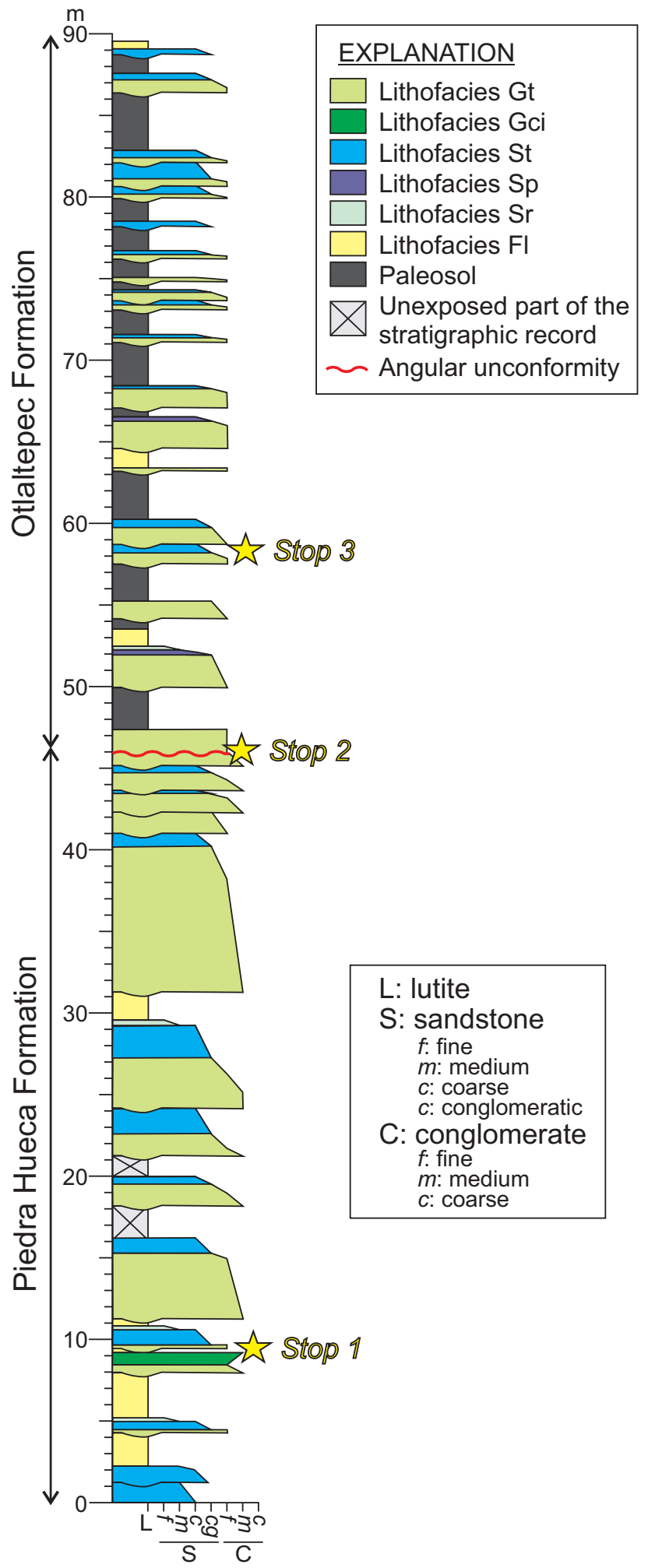

Figure 3 Representative stratigraphic column of the Piedra Hueca and Otlaltepec Formations exposed along the Magdalena Creek (modified from Martini et al., 2016). For a detailed description of the different lithofacies that compose the column see Table 1. laterally continuous sandstones with upper-plane lamination (lithofacies Sh; Figure 4d) are locally alternated with cross-bedded lithofacies and are interpreted as flash-flood-deposits (e.g. Miall, 2006). Based on the analogy with present-day sedimentary environments, the Piedra Hueca Formation has been interpreted as a proximal to intermediate alluvial fan or braided fluvial system (Martini et al., 2016).

Sandstones from the Piedra Hueca Formation vary in composition from feldspatho-quartzose to quartzo-feldspathic (Figure 5). The integration of detailed sandstone petrography, U-Pb detrital zircon geochronology, and detrital garnet chemistry suggests that Mesoproterozoic-Neoproterozoic, granulite-facies metamorphic rocks of the Oaxacan Complex (Figure 1) were the main source of detritus for the Piedra Hueca Formation (Martini et al., 2016). Subordinate detrital contributions from Paleozoic metasedimentary rocks of the Acatlán Complex, upper Paleozoic granitoids of the Totoltepec pluton, and Lower Jurassic syn-rift volcanic rocks that were locally emplaced in eastern Mexico during Pangea breakup are also documented (Martini et al., 2016).

Fossils in the Piedra Hueca Formation are scarce. Morán-Zenteno et al. (1993) reported poorly preserved cycad leaves such as Otozamites ssp., which is ubiquitous in Lower and Middle Jurassic fluvial deposits of Mexico (Perrilliat and Castañeda-Posadas, 2013).

\subsection{OTLALTEPEG FORMATION}

The Otlaltepec Formation overlies in angular unconformity the Piedra Hueca Formation (Figure 6). The Otlaltepec Formation is composed of rhythmically alternating conglomerate to finegrained sandstone deposits emplaced by traction currents (lithofacies Gt, St, Sp, Sr in Table 1), finely laminated lutite $(\mathrm{Fl})$, and paleosols developed during prolonged periods of non-deposition in a subaerial environment (Figure 3; Martini et al., 2016). Based on these lithofacies assemblage, the Otlaltepec Formation has been interpreted as an overbank environment that was intermittently 

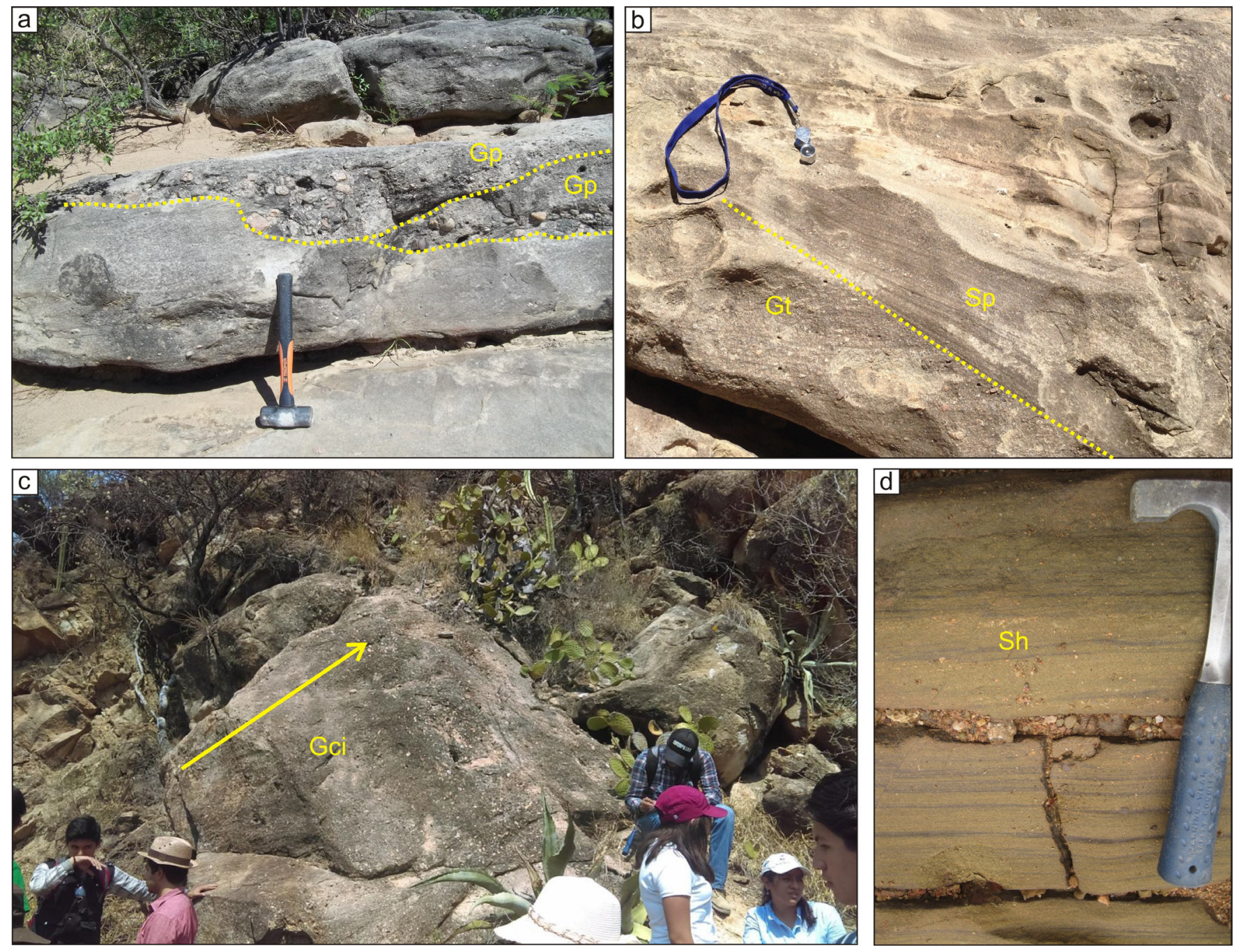

Figure 4 Photographs showing details of conglomerate and sandstone deposits that compose the Piedra Hueca Formation: (a) scoopshaped conglomerates of the Gp lithofacies; (b) coarse- and medium-grained sandstone deposits of lithofacies Sp, displaying planar cross bedding; (c) inversely-graded, poorly-sorted conglomerate interpreted as lithofacies Gci; (d) tabular-shaped, coarse-grained sandstone deposits representative of lithofacies Sh, which shows upper-regime plane lamination.

flooded during high-water stages and with subaerial exposition during low-water periods, favoring pedogenesis and the development of paleosols (Martini et al., 2016).

Sandstones from the Otlaltepec Formation vary in composition from feldspatho-quartzose to quartzoarenites (Figure 5; Martini et al., 2016). Petrographic data integrated with U-Pb detrital zircon geochronology and detrital garnet chemistry suggest that the Otlaltepec Formation was mostly derived from Mesoproterozoic-Neoproterozoic metamorphic rocks of the Oaxacan Complex as well as upper Paleozoic granitoids of the Totoltepec pluton (Figure 1; Martini et al., 2016). Subordinate detrital contributions from Paleozoic metasedimentary rocks of the Acatlán Complex and Jurassic syn-rift volcanic rocks emplaced in eastern Mexico during Pangea breakup were also documented (Martini et al., 2016).

In contrast to the Piedra Hueca Formation in which fossils are scarce and poorly preserved, sedimentary rocks of the Otlaltepec Formation con- 
Table 1. Synthesis of the lithofacies (Miall, 2006) that compose the stratigraphic column representative of the Piedra Hueca and Otlaltepec Formations

\begin{tabular}{|c|c|c|}
\hline Lithofacies code & Description & Interpretation \\
\hline Gt & $\begin{array}{l}\text { Scoop-shaped bodies of trough-cross-bedded conglomerate } \\
\text { typically cut into each other both laterally and vertically. }\end{array}$ & $\begin{array}{l}\text { Channel fill associated to low-sinuosity, braided } \\
\text { drainages }\end{array}$ \\
\hline Gci & $\begin{array}{l}\text { Clast- to matrix-supported, poorly-sorted, conglomerate showing } \\
\text { inverse grading. Beds of this lithofacies } \\
\text { have sharp but non-erosional relationship with underlying deposits. }\end{array}$ & High-strength, plastic debris-flow-deposit \\
\hline St & $\begin{array}{l}\text { Fine- to very coarse-grained sandstone displaying trough } \\
\text { cross-bedding. }\end{array}$ & Sinuous-crested and linguoid (3D) dune \\
\hline $\mathrm{Sp}$ & Fine-to coarse-grained sandstone displaying planar cross-bedding. & Transverse and linguoid (2D) dune \\
\hline $\mathrm{Sr}$ & Very fine- to coarse-grained sandstone displaying ripple cross-lamination. & Ripples (lower flow regime) \\
\hline $\mathrm{Fl}$ & $\begin{array}{l}\text { Horizontally interlaminated mudstone, siltstone, and very fine-grained } \\
\text { sandstone. }\end{array}$ & Deposit formed under lower plane bed regime \\
\hline
\end{tabular}

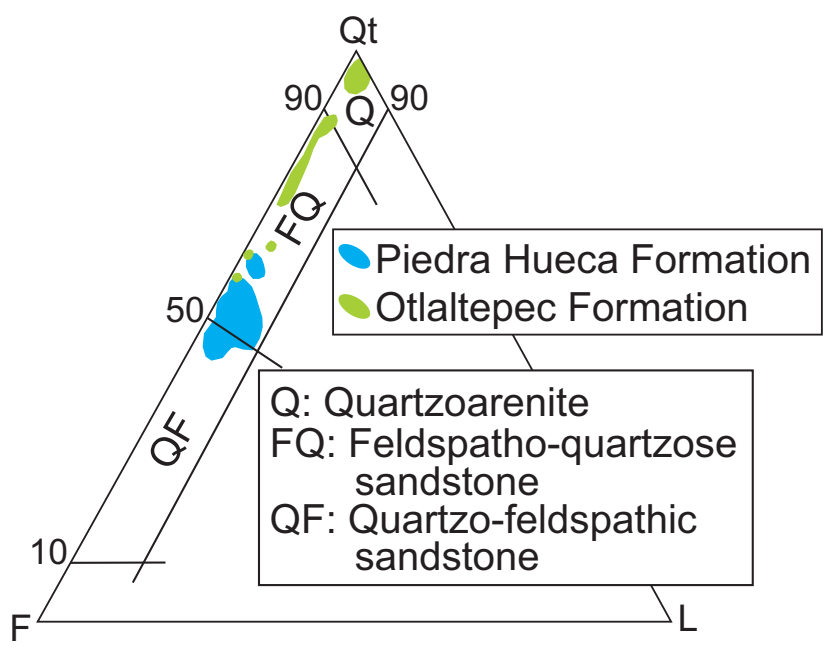

Figure 5 QtFL (Garzanti, 2016) diagram showing the sandstones composition of the Piedra Hueca and Otlaltepec Formation (modified from Martini et al., 2016).

tain abundant fossil leaves of Bennettitales, trunk molds, and minor amounts of fern and cycads leaves (Cruz-Cruz, 2012).

\subsection{TEGTONIC IMPLICATIONS}

Because of its paleogeographic position along the nascent plate boundary between North and South America, Mexico represents a key area for reconstructing Pangea breakup. However, in the last decades, the progressive fragmentation of Pangea has been reconstructed in Mexico mostly on the basis of regional-scale geometrical considerations and geophysical data, most of which are the property of oil companies (e.g. Pindell, 1985;
Ross and Scotese, 1988; Pindell and Kennan, 2009). To date, only few authors have been able to document major displacements along Jurassic faults in Mexico (e.g. Alaniz-Alvarez et al., 1996; Martiny et al., 2012). This is mostly due to the overprinting of Late Cretaceous and Paleocene tectonic events produced multiple episodes of fault reactivation that, in most cases, obliterated any evidence of major displacements during Jurassic time. The stratigraphic record exposed in the Otlaltepec Basin offers a great example of how Jurassic faults that participated to Pangea breakup can be indirectly recognized using a detailed provenance analysis of clastic rocks. In fact, according to Martini et al. (2016), the change in sandstone provenance documented in the Jurassic succession of the Otlaltepec Basin is a manifestation of the progressive continental attenuation and exhumation of different crustal blocks. More in detail, the sudden enrichment in detritus coming from the Totoltepec pluton in the Otlaltepec Formation has been interpreted as the result of rapid exhumation of this intrusive body along the Matanza fault, which is a W-trending, sinistral normal structure that bounds the Otlaltepec Basin to the south (figures 1 and 2). According to this interpretation, the Pangea breakup in southern Mexico is expressed by major sinistral block motions along W-trending faults. This is in agreement with regional-scale plate tectonic reconstructions, which predict that southern Mexico was located to the north-west of its present-day position by the beginning of Mesozoic time in order to avoid the overlap between 


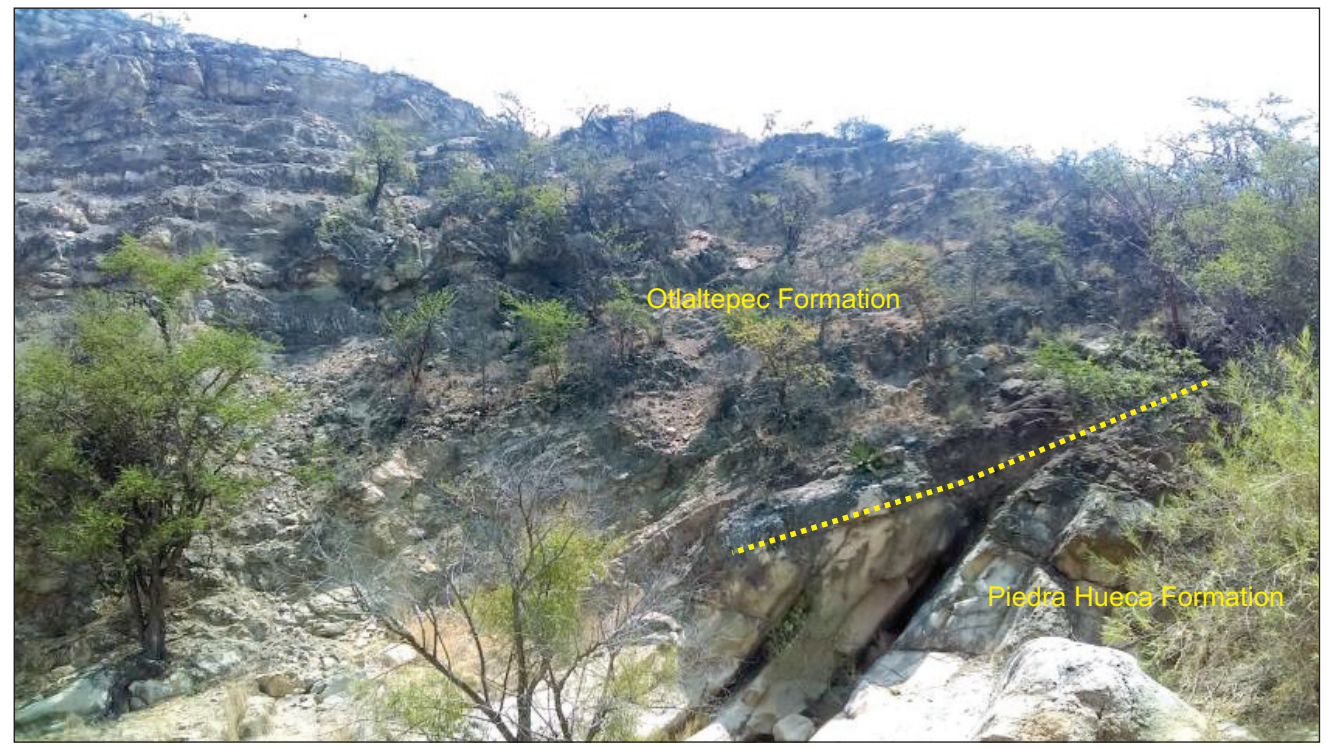

Figure 6 Exposure of the angular unconformity that participants will observe between the Piedra Hueca and Otlaltepec Formations.

North and South America in the reconstruction of Pangea (e.g. Pindell and Kennan, 2009).

\subsection{PALEOGLIMATIG IMPLIGATIONS}

As noted by Martini et al. (2016), the provenance change documented in the stratigraphic record of the Otlaltepec Basin can be interpreted as the result of exhumation and subsequent erosion of different crustal blocks composed of different lithological assemblages. However, this process alone cannot explain the dramatic enrichment in quartz (up to $98 \%$ ) in most sandstone samples from the Otlaltepec Formation (Figure 5). In fact, although they were derived from different combinations of metamorphic and plutonic assemblages, both the Piedra Hueca and Otlaltepec Formations were sourced by rocks that display a quartzo-feldspathic composition. In lights of this consideration, the strong quartz enrichment in sandstones from the Otlaltepec Formation can be explained only assuming feldspar dilution by chemical weathering under humid climatic conditions (e.g. Basu, 1985; van der Kamp, 2010). Adopting the tectono-stratigraphic reconstruction proposed by Martini et al. (2016), the increase in quartz content coincides with the exhumation of the Totoltepec pluton.
Therefore, we suggest the possibility that the tectonic exhumation and uplift of the Totoltepec pluton could have favored the progressive landscape fragmentation, producing local climatic variations that controlled the composition of sediments. At present, this hypothesis has not been exhaustively explored and, therefore, the stratigraphic record of the Otlaltepec Basin offers some perspective for future studies focused on the reconstruction of climatic conditions under which the Jurassic successions were deposited.

\section{The Tezoatlán Basin}

The Tezoatlán Basin is located in the vicinity of the homonymous town, south of Huajuapan de León in the state of Oaxaca (Figures 1 and 7a). The northern boundary of the Tezoatlán Basin is represented by the WNW-trending Río Salado fault (Figure 1), which is a kilometer-scale, multi-reactivated structure that produced major sinistral normal displacements during Jurassic time (Martiny et al., 2012). The eastern and western boundaries are buried under Cenozoic volcanic rocks, whereas the southern limit with the coeval Tlaxia- 
co Basin (Figure 1) has not been studied in detail. As for the Otlaltepec Basin, the Tezoatlán Basin is composed of an approximately 1000 m thick continental clastic succession that contains abundant Jurassic fossil flora (Erben, 1956; Morán-Zenteno et al., 1993). This clastic succession conformably overlies Lower Jurassic, mafic to felsitic volcanic rocks of the Diquiyú Formation (Figure 7b; Durán-Aguilar, 2013), which have been interpreted as a manifestation of the syn-rift magmatism that accompanied the breakup of Pangea (Martini and Ortega-Gutiérrez, 2016). Differing from the Otlaltepec Basin, in which the oldest marine deposits are Early Cretaceous in age, the continental succession in the Tezoatlán Basin is overlain by marine rocks that contain a Bajocian-Bathonian fossil fauna (Erben, 1956; Sandoval and Westermann, 1986; Cantú-Chapa, 1998). In light of these data, some authors proposed that Mexico was progressively transgressed from south to north by Pacific marine waters during Mesozoic time (Cantú-Chapa, 1998). However, this scenario contrasts with the most widely accepted idea of a transgression driven by sea-floor spreading in the Gulf of Mexico and Atlantic Ocean, as it is suggested by the affinity of several Jurassic ammonites with faunal assemblages of the Tethys (e.g. Sandoval and Westernmann, 1986; Olóriz et al., 2000; Olóriz et al., 2003). The Jurassic clastic succession exposed in the Tezoatlán Basin has been subdivided into three stratigraphic units that, from the base to the top, are: the Rosario and Cualac Formation and the Tecocoyunca Group (Figure 7b; Erben, 1956).

During this field trip, participants will have the opportunity to observe different sedimentological and paleontological aspects of the three clastic units exposed in the Tezoatlán Basin. We will discuss the tectonic setting and climatic conditions under which the sedimentary succession was deposited and compare the tectono-stratigraphic and paleoenvironmental evolution of the Tezoatlán and Otlaltepec Basins.

\subsection{ROSARIO FORMATION}

The Rosario Formation is dominantly composed of conglomerate and minor sandstone lenses, lutite, and coal (Erben, 1956; Morán-Zenteno et al., 1993; Durán-Aguilar 2013). Conglomerate deposits are dominantly matrix-supported, poorly-sorted, and locally display crude stratification, imbrication, and inverse grading (Figure 8a; Durán-Aguilar, 2013). Based on these characteristics, diverse authors interpreted the Rosario Formation as the stratigraphic record of a high-energy fluvial stream and its associated flood plain environment (Morán-Zenteno et al., 1993; Durán-Aguilar, 2013). Conglomerate and sandstone deposits of the Rosario Formation are mostly composed of volcanic clasts (Figure 8b) that have been interpreted to be derived from the underlying Diquiyú Formation (Morán-Zenteno et al., 1993). However, a detailed provenance study of the Rosario Formation has not been carried out.

Because of its fossil flora, the Rosario Formation has been object of several studies by different authors during the last decades. More in detail, previous authors documented in the Rosario Formation a new species of male and female reproductive organs of Bennettitales (Williamsoniaceae), as well as the new genus Mexiglossa Delevoryas et Person (Delevoryas, 1966, 1968, 1969; Delevoryas and Person, 1975; Person, 1976). Genus Mexiglossa suggests an affinity with Gondwana, whereas the reproductive organs of Williamsoniaceae are similar to those reported in Yorkshire in the United Kingdom and Rajmahall Hills in India. In addition, Ortega and Velasco-de León (2015) collected an $8 \mathrm{~m}$-long fossil trunk that has been determined as Agathoxylon Harting. Moreover, the finding of the Nehvizdyella Kvaček, Falcon-Lang et Dasková includes the Tezoatlán area in the distribution of the Ginkgoales order (Lozano-Carmona and Velasco-de León, 2016). Representative samples of the floral content recovered from the Rosario For- 

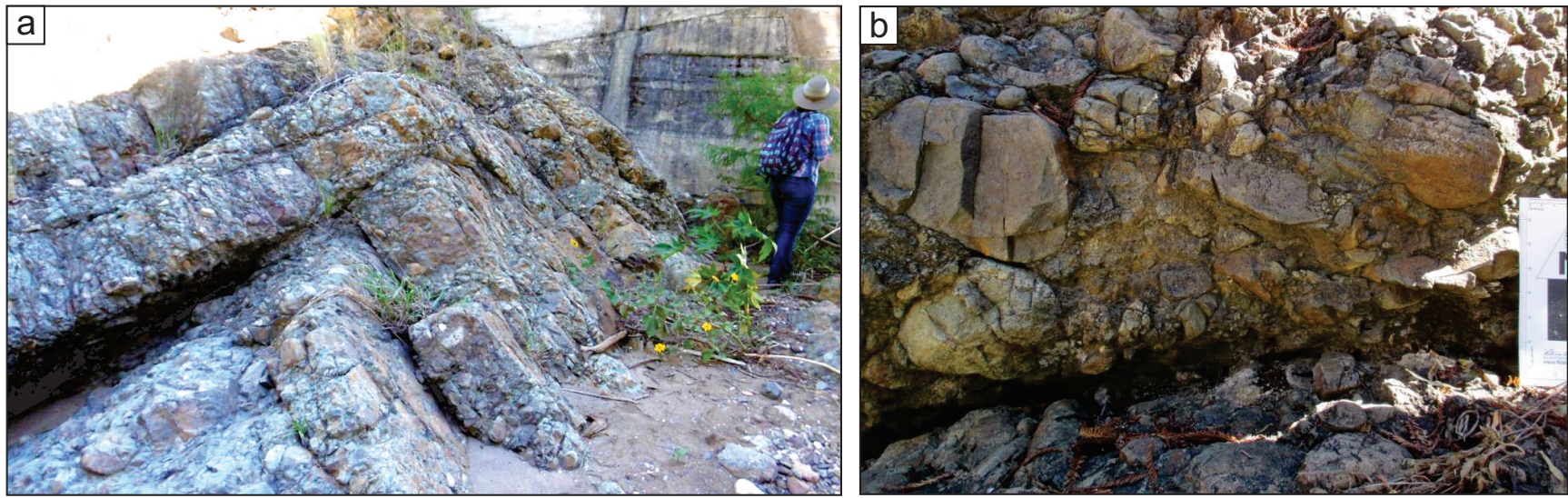

Figure 8 Photographs showing details of conglomeratic deposits of the Rosario Formation: (a) clast- to matrix-supported, poorlysorted conglomerate showing crude bedding; (b) imbricated volcanic clasts in a conglomeratic deposit.

mation will be observed at the Geological Museum of Rosario Nuevo during the second day of the field trip.

\subsection{GUALAC FORMATION}

The Cualac Formation overlies the Rosario Formation in a transitional contact. The Cualac Formation is dominantly composed of conglomerate and conglomeratic sandstone interbedded with minor coarse- to fine-grained sandstones and lutite (Figure 9a; Erben, 1956; Morán-Zenteno et al., 1993; Durán-Aguilar, 2013). A detailed sedimentological study of this unit has not been carried out. Some authors interpreted the Cualac Formation as the proximal part of alluvial fans developed in a high relief region (Morán-Zenteno et al., 1993), whereas other authors suggested that this unit represents the stratigraphic record of a meandering river (Durán-Aguilar, 2013). Exposures observed during the field trip will permit an exhaustive discussion on these two competing interpretations. Differing from the underlying Rosario Formation, which is mostly composed of volcanic clasts, the Cualac Formation is dominantly made up of fragments of quartz and quartz-rich metamorphic rocks (Figure 9b; Morán-Zenteno et al., 1993; Durán-Aguilar, 2013). To date, an exhaustive provenance analysis of these clastic rocks has not been published.
Fossil flora in the Cualac Formation exposed in the Tezoatlán Basin consists of Mexiglossa varia (Figure 10a), as well as Zamites oaxacenis, Z. diquiyui, Anomozamites, Otozamites hespera, Ptillophyllum sp. and Williamsoniaceae flowers (Guzmán and Velasco-de León, 2014). A detailed cuticle analysis shows that epidermal cells of Mexiglossa varia recovered from the Tezoatlán area are rectangular in shape, display slightly wavy walls, sunken stomas, and are arranged in rows with apparent disorder (Figure $10 \mathrm{~b})$. These characteristics permit to differentiate this genus from Glossopteris Brongniart.

\subsection{TEGOGOYUNGA GROUP}

The Tecocoyunca Group overlies the Gualac Formation in a transitional contact. According to Erben (1956), the Tecocoyunca Group can be subdivided into five different formations that are: the Zorrillo, Taberna, Simon, Otatera, and Yucuñuti Formations. However, as pointed out by Morán-Zenteno et al. (1993), the lithological and sedimentological differences between these formations are often subtle and, therefore, the recognition of these units on the field is not easy and may be subjective. In general terms, the lower stratigraphic part of the Tecocoyunca Group is dominantly composed of sandstone, black shale, and coal containing abundant fossil flora (Figure 

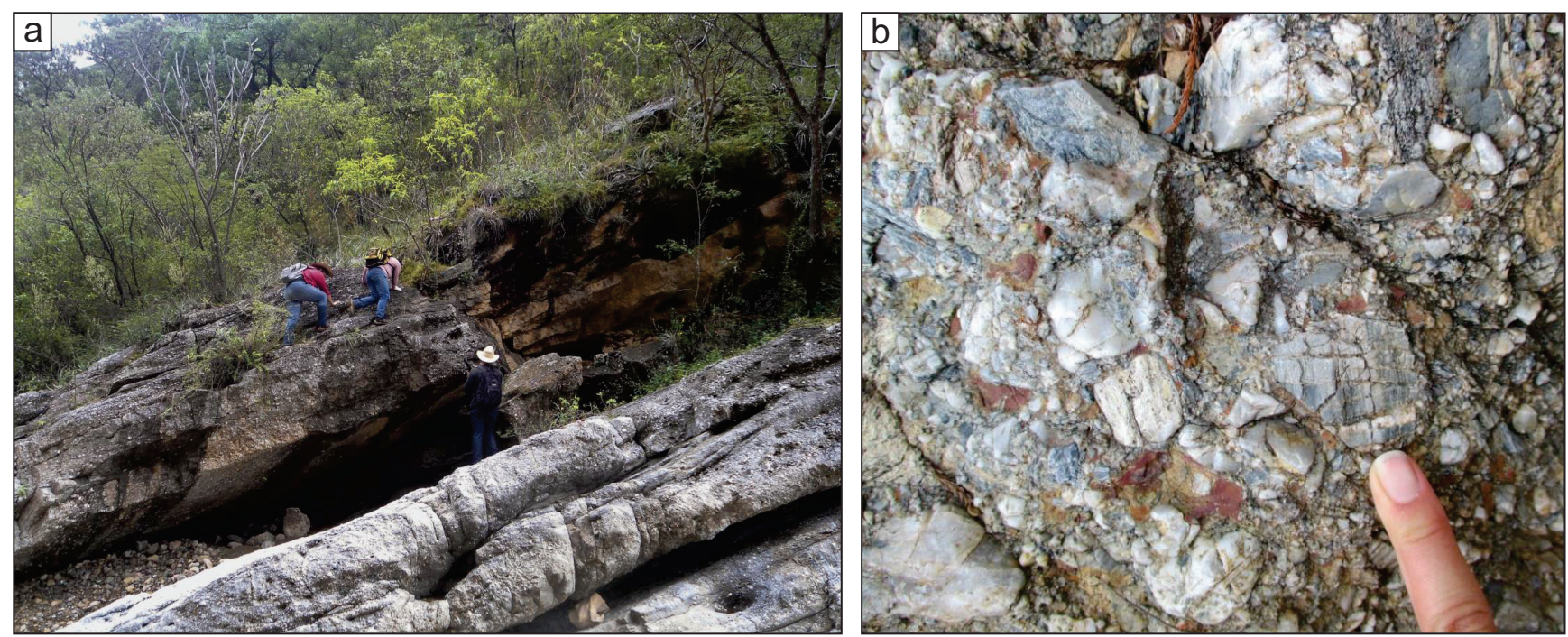

Figure 9 Photographs showing details of conglomerate, sandstone, and lutite that compose the Cualac Formation: (a) superposed meter-thick successions showing a typical fining-upward trend; (b) clast-supported, poorly-sorted conglomerate composed of subangular clasts derived from quartz-rich metamorphic rocks.
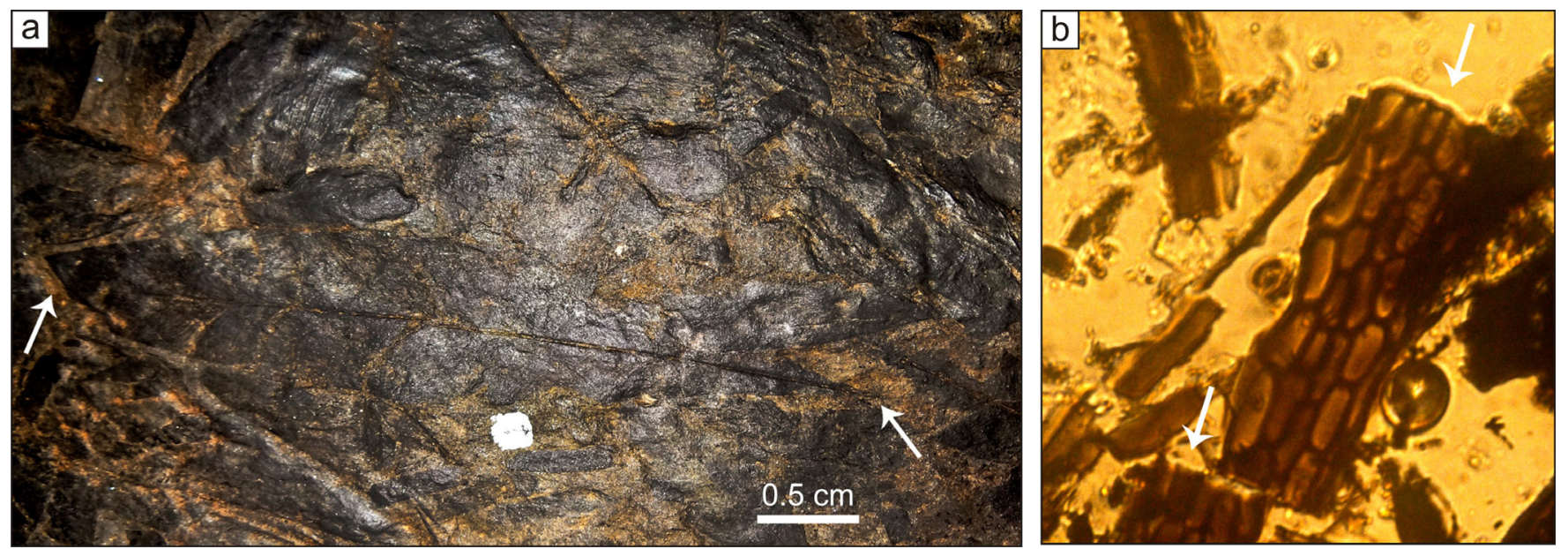

Figure 10 (a) Leaf of Mexiglossa varia in finely laminated lutite of the Cualac Formation. Arrows point to base and apex of the leaf. (b) Photomicrography of leaf cuticle of Mexiglossa varia.

11; Morán-Zenteno et al., 1993). On the other hand, the upper stratigraphic part is composed of sandstone and shale with marine mollusks and ammonites of Bajocian and Bathonian age such as Duashnoceras Westermann, Leptosphinctes Buckman, and Parastrenoceras Ochoterena (Erben, 1956; Sandoval and Westermann, 1986; Cantú-Chapa, 1998). Based on the sedimentological and paleontological characteristics, the succession of the Tecocoyunca Group has been interpreted as a flood-plain environment with marsh areas that progressively evolved into a littoral to shallow-water marine environment connected to an open sea (Morán-Zenteno et al., 1993).

As for the Cualac Formation, sandstones of the Tecocoyunca Group are mainly composed of quartz and quartz-rich metamorphic fragments (Durán-Aguilar, 2013). However, a detailed provenance analysis of these sandstones is presently not available. 


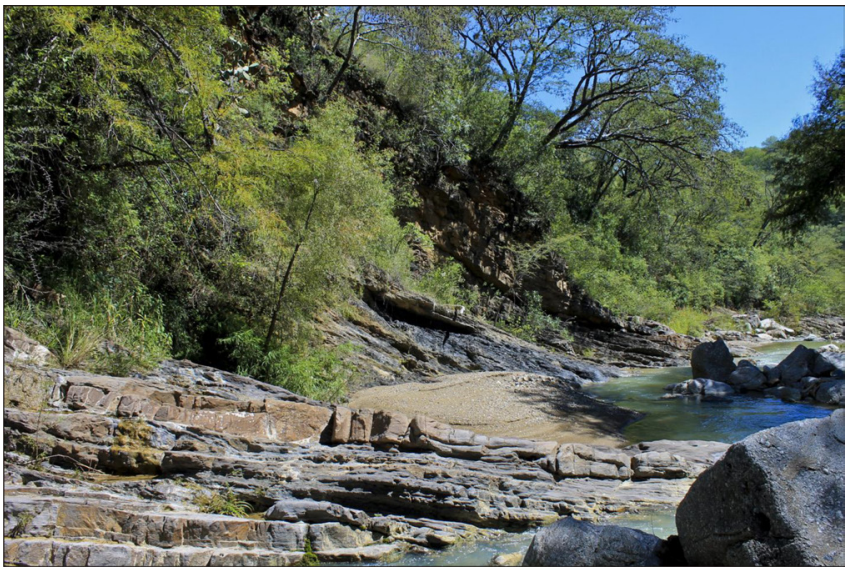

Figure 11 Exposure of continental sandstone and lutite that compose the lower stratigraphic part of the Tecocoyunca Group.

The abundant fossil flora contained in the Tecocoyunca Group has been object of study by several authors. Wieland (1914), Delevoryas (1971), and Silva-Pineda (1984) originally documented various specimens of Bennettitales, Cycadales, Filicales, and Equisetales. Subsequently, new findings from various authors pointed out the presence of Ginkgoales, Caytoniales, Czekanowskiales, Podozamitales, and Filicales in the lower stratigraphic part of the Tecocoyunca Group (Rojas-Chávez, 2010; Lozano-Carmona, 2012; Lozano-Carmona and Velasco-de León 2014; Velasco-de León et al., 2013, 2014).

\subsection{TEGTONIC IMPLICATIONS}

As it has been documented in the Otlaltepec Basin, the Jurassic clastic succession exposed in the Tezoatlán Basin records a major compositional change. Whereas conglomerate and sandstone of the Rosario Formation are mostly composed of volcanic clasts apparently sourced by the underlying Diquiyú Formation, clastic deposits of the Cualac Formation and Tecocoyunca Group dominantly consists of quartz and quartz-rich metamorphic fragments derived from a crystalline basement (Morán-Zenteno et al., 1993; Durán-Aguilar, 2013). As it has been suggested for the Otlaltepec Basin, the compositional change in the succession exposed in the Tezoatlán Basin could be the result of the exhumation of different basement blocks during the fragmentation of Pangea. Unfortunately, a detailed provenance analysis for these units is not available. Therefore, recognizing the major faults that controlled the exhumation of basement blocks and the consequent change in composition in the clastic succession of the Tezoatlán Basin is not presently possible. The Río Salado fault is a major NNW-trending Jurassic structure along which the Tezoatlán Basin is directly juxtaposed to Paleozoic quartz-rich metasedimentary rocks of the Acatlán Complex (Figure 1; Martiny et al., 2012). On the field, we will take the occasion to discuss the possibility that the progressive enrichment in quartz and quartz-rich metamorphic fragments in the Cualac Formation and Tecocoyunca Group could be produced by the exhumation of metasedimentary rocks of the Acatlán Complex along the Río Salado fault.

\subsection{PALEOGLIMATIC IMPLICATIONS}

The foliar area analysis conducted on various specimens of gymnosperms extracted from the Rosario Formation suggests that this unit was deposited under a seasonal climate characterized by alternating periods of high temperature associated with severe droughts and periods of high rainfall (Velasco-de León et al., 2013). On the other hand, the presence of Ceratozamia and Mexiglossa varia in the Cualac Formation indicate that this unit was deposited under climatic conditions characterized by lower temperature and higher humidity (Velasco-de León et al., 2013). Based on these considerations, a major change in climatic conditions can be documented in the Tezoatlán area during Jurassic time. As in the Otlaltepec Basin, such a climatic change seems to coincide with a major provenance change in the sedimentary succession.

\section{Conclusions}

The integration of sandstone petrologic and paleontologic data suggests that deposition of Jurassic 
clastic successions in the Otlaltepec and Tezoatlán Basins was accompanied by major changes in climatic conditions. More in detail, an evolution from dry or seasonal to humid conditions is supported by sandstone whole-rock composition and fossil flora. Interestingly, these climatic variations coincide with major changes in provenance of clastic rocks. Provenance changes in the Otlaltepec and Tezoatlán successions are interpreted as the manifestation of the complex history of exhumation of different fault-bounded lithospheric blocks that accompanied Pangea breakup. Based on these considerations, we preliminarily suggest that the progressive fragmentation of Pangea produced a major topographic reorganization that favored local variations in climatic conditions and the diversification of floral assemblages in Mexico during Jurassic time.

\section{Field trip}

\subsection{DAY ONE}

During the first day of the trip participants will observe representative exposures of the Otlaltepec Basin along the Magdalena Canyon (Figure 3). This canyon offers the possibility of examining in detail the sedimentological and petrological characteristics of the Piedra Hueca and Otlaltepec Formations, as well as their fossil flora.

\subsubsection{STOP 1: PIEDRA HUECA FORMATION (18'16'59.92'N, 97०48'9.77'W)}

At this outcrop we will observe conglomerate, sandstone, and lutite representative of the Piedra Hueca Formation. Conglomerate deposits are dominantly trough- to planar-cross-bedded (lithofacies Gt and Gp) and grade upward into conglomeratic- to fine-grained sandstone that show trough- to planar-cross-bedding (lithofacies St, Sp). Locally, drapes of horizontally laminated, very fine-grained sandstone and lutite (lithofacies Fl) overlie sandstone deposits. This lithofacies assemblage is interpreted to reflect the seasonal decrease in energy of a braided fluvial system. Locally, deci- meter-thick deposits composed of tabular-shaped, laterally continuous sandstones with upper-plane lamination are alternated with cross-bedded lithofacies, and they are interpreted to be emplaced during flash-flood events. Conglomerate and sandstone deposits are dominantly composed of quartzo-feldspathic clasts derived from granulite-facies rocks of the Oaxacan Complex. Greenschist-facies metamorphic clasts sourced by the Acatlán Complex are also present. Detailed petrographic and geochronologic data will be presented at the outcrop in order to stimulate the discussion on the provenance of this stratigraphic unit.

\subsubsection{STOP 2: ANGULAR UNCONFORMITY BETWEEN THE PIEDRA HUECA AND OTLALTEPEC FORMATIONS (18'17'0.35'N, 9748'9.73'W)}

The goal of this stop is to observe an excellent exposure of the stratigraphic relationship between the Piedra Hueca and Otlaltepec Formations. As we will observe on the field, the contact between these two units is an angular unconformity where $\sim 50^{\circ}$-dipping beds of the Piedra Hueca Formation are overlain by $\sim 20^{\circ}$-dipping strata of the Otlaltepec Formation. The aforementioned unconformity is interpreted as the result of exhumation of the Totoltepec pluton along the normal sinistral Matanza fault. Such interpretation is supported by the enrichment in clasts derived from the Totoltepec pluton in the Otlaltepec Formations. Evidence of syn-sedimentary faulting in the Otlaltepec Basin area is given by the widespread occurrence of centimeter- to meter-scale, syn-sedimentary normal faults throughout the entire succession. Some of these faults will be observed and discussed at this outcrop.

\subsubsection{STOP 3: OTLALTEPEC FORMATION $\left(18^{\circ} 17^{\prime} 2.90^{\prime} \mathrm{N}\right.$, 97०48'12.49'W)}

At this stop, participants will observe a representative succession of the Otlaltepec Formation, which is composed of rhythmically alternating conglomerate to fine sandstone deposits emplaced by traction currents (lithofacies Gt, St, Sp, Sr in Table 1), finely laminated lutite (lithofacies $\mathrm{Fl}$ ) with abundant cycad and fern leaves, and paleosols de- 
veloped during prolonged periods of non-deposition in a subaerial environment. Conglomerate and sandstone deposits are dominantly sourced by quartzo-feldspathic rocks of the Totoltepec pluton and Oaxacan Complex. Detailed petrographic and $\mathrm{U}-\mathrm{Pb}$ geochronologic data on detrital zircons will be presented at this outcrop in order to discuss the provenance of the Otlaltepec Formation. Despite the quartzo-feldespathic composition of source rocks, the Otlaltepec Formation displays a high enrichment in quartz (up to $98 \%$ of the total framework grains). This strong enrichment in quartz is explained here assuming that feldspar dilution was produced by chemical weathering under humid climatic conditions (e.g. Basu, 1985; van der Kamp, 2010).

\subsection{DAY TWO}

During the second day of the trip, participants will observe representative exposures of the Tezoatlán Basin along the Rosario Nuevo Canyon (Figure 12). This canyon offers the opportunity of examining in detail the sedimentologic and petrologic characteristics of the stratigraphic units that compose the Tezoatlán Basin, as well its fossil flora content.

\subsubsection{STOP 4: DIQUIYÚ FORMATION $\left(17^{\circ} 36^{\prime} 6.78\right.$ ' $N$, 97050'56.97' $W$ )}

At this stop, we will observe andesitic volcanic rocks of the Diquiyú Formation that represents the basement of the Tezoatlán clastic succession. The Diquiyú Formation is interpreted as the source for the overlying Rosario Formation (Morán-Zenteno et al., 1993). Therefore, the aim of this stop is to observe textural and compositional details of the Diquiyú Formation in order to compare these volcanic rocks with volcanic clasts of the Rosario Formation.

\subsubsection{STOP 5: ROSARIO FORMATION $\left(17^{\circ} 36^{\prime} 9.35^{\prime}\right.$ N, 97050'54.39'W)}

At this stop, participants will observe an excellent exposure of the Rosario Formation. This unit is mostly composed of clast- to matrix-supported, poorly-sorted, and crudely-bedded conglomerate deposits that have been interpreted by previous authors as the stratigraphic record of a high-energy fluvial stream (Morán-Zenteno et al., 1993). Clasts in the Rosario Formation are mostly composed of volcanic rocks that show textural and compositional similarities with the Diquiyú Formation.

\subsubsection{STOP 6: CUALAC FORMATION $\left(17^{\circ} 36^{\prime} 18.2^{\prime}{ }^{\prime} N\right.$, 97050’40.9' $W$}

At this outcrop, we will observe representative exposures of the Cualac Formation. At this point, the Cualac Formation is composed of conglomerate, coarse- to fine-grained sandstone, and shale that display a variety of sedimentary structures such as through to planar cross bedding, imbrication, and ripple marks. After a careful observation of the sedimentological characteristics of the Cualac Formation, we will evaluate the possibility that this unit was deposited in a proximal alluvial fan environment as it was suggested by Morán-Zenteno et al. (1993) or in a meandering river as it was proposed by Durán-Aguilar (2013). Furthermore, participants will observe that clastic deposits of the Cualac Formation display a dramatic change in composition relative to the Rosario Formation. In fact, the Cualac Formation is dominantly composed of quartz and quartz-rich metamorphic fragments. We will discuss on the field the significance of such a compositional change in the clastic stratigraphic record.

At this outcrop, finely laminated shale layers preserve impressions of leaves that have been determined as Mexiglossa varia, Zamites, Otozamites, and Anomozamites.

\subsubsection{STOP 7: LOWER TECOCOYUNGA GROUP (17036'22'’ $\left.\mathrm{N}, 97^{\circ} 50^{\prime} 38.8^{\circ}{ }^{\circ} W\right)$}

The goal of this stop is to observe excellent exposures of the lower stratigraphic part of the Tecocoyunca Group, which is composed here of a succession of sandstone, shale, and coal that has been interpreted as the stratigraphic record of a flood-plain environment (Morán-Zenteno et al., 1993). Shale of this outcrop preserves leaves impressions that will be described on the field in order 
to discuss the climatic conditions under which this unit was deposited.

\subsubsection{STOP 8: UPPER TECOCOYUNGA GROUP, (17036'29.6'N, 97050'38.7'W)}

At this outcrop, participant will observe the transition from the lower to the upper parts of the Tecocoyunca Group. This transition in marked by a gradual change from continental to littoral and shallow-marine sedimentary environment that was the result of a regional marine transgression in the Tezoatlán area. Shallow marine deposits are composed of rhythmically interbedded sandstone and calcareous shale that contain Bajocian and Bathonian fossils of bivalves and ammonites such as Oppelia, Leptosphinctes, Parastrenocera, Trigonia, Myophorella, and Vaugonhia.

\subsubsection{STOP 9: GEOLOGICAL MUSEUM OF ROSARIO NUEVO (17'36'11.56'N, 97'51'13.7'W)}

We will take the occasion to visit the regional museum of Rosario Nuevo, where representative fossils from the continental to marine succession of the Tezoatlán Basin are exposed.

\subsubsection{STOP 10: CERRO DE LAS MINAS ARCHEOLOGICAL SITE}

If time permits, we will take the opportunity to visit the archeological site "Cerro de las Minas" that is located northward of Huajuapan de León (Figure 2). This site belongs to the Nuiñe culture, and it was founded during the Preclassic period and reached its climax throughout the early Classic period between 400 and $800 \mathrm{CE}$. In the course of this period, other major cities flourished such as Monte Alban in the state of Oaxaca and Teotihuacan in the Valley of Mexico. Cerro de las Minas is located in a hill that dominates the valley of Huajuapan de León. This large hill was in a strategic position over the farmlands of the valley, permitting the absolute control on the trade routes that crossed this region. The site contains a number of settlements and was reserved for the elite of the area during that time. Cerro de las Minas is the only archeological site of the Mixteca Baja region open to the public.

\section{Acknowledgements}

Data presented in this field trip guide are the direct result of different research projects funded by PAPIIT (Programa de Apoyo a Proyectos de Investigación e Innovación Tecnológica) grants IA100214 and IA102216 to Michelangelo Martini and grants IN106010-3 to Patricia Velasco-de León. We thank Francisco Vega Vera and two anonymous reviewers for their helpful comments that greatly improved this field trip.

\section{References}

Alaniz-Alvarez, S.A., van der Heyden, P., NietoSamaniego, A.F., Ortega-Gutiérrez, F., 1996, Radiometric and kinematic evidence for Middle Jurassic strike-slip faulting in southern Mexico related to the opening of the Gulf of Mexico: Geology, 24, 443-446.

Basu, A., 1985, Influence of climate and relief on composition of sands released at source areas, in Zuffa, G.G., (ed.), Provenance of arenites, NATO Advanced Study Institute Series, Dordrecht, Netherlands, D. Reidel, 148, 1-18.

Campos-Madrigal, E., Centeno-García, E., Mendoza-Rosales, C.C., Silva-Romo, G., 2013, Sedimentología, reconstrucción paleoambiental y significado tectónico de las sucesiones clásticas del Jurásico Medio en el área de Texcalapa, Puebla-Huajuapan de León, Oaxaca: Revisión de las formaciones Ayuquila y Tecomazúchil: Revista Mexicana de Ciencias Geológicas, 30, 34-50.

Cantú-Chapa, A., 1998, Las transgresiones jurásicas en México: Revista Mexicana de Ciencias Geológicas, 15, 25-37. 
Cruz-Cruz, M.A., 2012, Análisis estratigráfico de la secuencia Jurásica de la región de Santo Domingo Tianguistengo, Oaxaca, Santa Cruz Nuevo, Puebla: México, D.F., Instituto de Geofísica, Universidad Nacional Autónoma de México, Bachelor's thesis, 109 p.

Delevoryas, T., 1966, Hunting fossil plants in México: Discovery, 2, 7-31.

Delevoryas, T., 1968, Jurassic paleobotany in Oaxaca (resumen), in Guidebook for the 1968 Annual Meetings, Mexico City, Geological Society of America, 10-14.

Delevoryas, T., 1969, Glossopterid leaves from the Middle Jurassic of Oaxaca, México: Science, 165, 895-896.

Delevoryas, T., 1971, Biotic provinces and the Jurassic-Cretaceous floral transition (resumen), in Proceedings North American Paleontology Convention, September 1969, Chicago, Lawrence Kan Allen Press, 1660-1674.

Delevoryas, T., Person, C.P., 1975, Mexiglossa varia gen. et sp. nov., a new genus of glossopteroid leaves from the Jurassic of Oaxaca, México: Palaeontographica, Abteilung B, 154, 114-120.

Dickinson, W.R., Lawton, T.F., 2001, Carboniferous to Cretaceous assembly and fragmentation of Mexico: Geological Society of America Bulletin, 113, 1142-1160.

Durán-Aguilar, R.F., 2013, Sedimentología y geocronología de los lechos rojos del Jurásico, Región Norte de la Cuenca de Tlaxiaco, Tezoatlán, Oaxaca; correlaciones y procedencia: México, D.F., Instituto de Geofísica, Universidad Nacional Autónoma de México, Master's thesis, $87 \mathrm{p}$.

Erben, H.K., 1956, El Jurásico Medio y el Caloviano de México, in XX Congreso Geológico Internacional, Monografía, D.F., México, 140 p.
Garzanti, E., 2016, From static to dynamic provenance analysis-Sedimentary petrology upgraded: Sedimentary Geology, 336, 3-13.

Goldhammer, R.K., 1999, Mesozoic sequence stratigraphy and paleogeographic evolution of northeast Mexico, in Bartolini, C., Wilson, J.L., Lawton, T.F., (eds.), Mesozoic Sedimentary and Tectonic History of NorthCentral Mexico: Geological Society of America, Special Paper, Boulder, Colorado, 340, 1-58.

Guzmán, M.D.S., Velasco-de León, M.P., 2014, Morfología foliar y cuticular de Mexiglossa varia del Jurásico Inferior de la Formación Cuarcítica Gualac Localidad Rosario Nuevo (resumen), in II Simposio de Paleontología en el sureste de México: Puerto Escondido, Universidad del Mar, 51.

van der Kamp, P.C., 2010, Arkose, subarkose, quartz sand, and associated muds derived from felsic plutonic rocks in glacial to tropical humid climates: Journal of Sedimentary Research, 80, 895-918.

Kirsch, M., Keppie, D.J., Murphy, B., Solari, L., 2012, Permian-Carboniferous arc magmatism and basin evolution along the western margin of Pangea: Geochemical and Geochronological Evidence from the Eastern Acatlán Complex, Southern Mexico: Geological Society of America Bulletin, 124, 1607-1628.

Lozano-Carmona, D.E., 2012, Paleoclima y flora fósil de Río Numi, Formación ZorrilloTaberna Indiferenciada, Oaxaca: México D.F., Facultad de Estudios Superiores Zaragoza, Universidad Nacional Autónoma de México, Bachelor's thesis, 170 p.

Lozano-Carmona, D.E., Velasco-de León, M.P., 2014, Primer registro de Czekanowskia Heer, 1876 (Gymnospermae, Czekanowskiales), del Jurásico de México, Memorias el II Simposio de Paleontología en el sureste de México, Universidad del Mar, Puerto Escondido, Oaxaca, México, 58. 
Lozano-Garmona, D.E., Velasco-de León, M.P., 2016, Primer registro de Eretmophyllum (Ginkgoales), en el Jurásico de México (resumen), in XVI Simposio Argentino de Paleobotánica y Palinología: La Plata, Asociación Paleontológica Argentina Suplemento, 52.

Martini, M., Ortega-Gutiérrez, F., 2016, Tectonostratigraphic evolution of eastern Mexico during the break-up of Pangea: A review: Earth-Science Review, DOI 10.1016/j. earscirev.2016.06.013.

Martini, M., Ramírez-Calderón, M., Solari, L., Villanueva-Amadoz, U., ZepedaMartínez, M., Ortega-Gutiérrez, F., ElíasHerrera, M., 2016, Provenance analysis of Jurassic sandstones from the Otlaltepec Basin, southern Mexico: Implications for the reconstruction of Pangea break-up: Geosphere, 12, 1-23.

Martiny, B.M., Morán-Zenteno, D.J., Tolson, G., Silva-Romo, G., López-Martínez, M., 2012, The Salado River fault: reactivation of an Early Jurassic fault in a transfer zone during Laramide deformation in southern Mexico: International Geology Reviews, 54, 144-164.

Miall, A.D., 2006, The Geology of Fluvial Deposits. Sedimentary facies, basin analysis, and petroleum geology: Heidelberg, Germany, Springer, 582 p.

Morán-Zenteno, D.J., Caballero-Miranda, G.I., Silva-Romo, G., Ortega-Guerrero, B., Gonzales-Torres, E., 1993, JurassicCretaceous Paleogeographic evolution of the northern Mixteca terrane, southern Mexico: Geofísica Internacional, 32, 453-473.

Olóriz, F., Villaseñor, A.B., González-Arreola, C., 2000, Geographic control on phenotype expression. The case of Hybonoticeras mundulum (Oppel) from the Mexican Altiplano, Lethaia, $33,157-174$.

Olóriz, F., Villaseñor, A.B., González-Arreola, C., 2003, Major lithostratigraphic units in land-outcrops of north-central Mexico and the subsurface along the northern rim of Gulf of Mexico Basin (Upper Jurassic-lowermost Cretaceous): a proposal for correlation of tectono-eustatic sequences, Journal of South American Earth Science, 16, 119-142.

Ortega C.E., Velasco-de León M.P., 2015, Maderas Jurásicas afines a las familias Araucariaceae y Podocarpaceae de las formaciones Tecomazúchil y Rosario, Oaxaca, XVI Simposio Argentino de Paleobotánica y Palinología, La Plata, Argentina, 95 p.

Ortega-Guerrero, B., 1989, Paleomagnetismo y Geología de las unidades clásticas Mesozoicas del área Totoltepec-Ixcaquixtla, estados de Puebla y Oaxaca: México, D.F., Instituto de Geofísica, Universidad Nacional Autónoma de México, tesis de maestría, 155 p.

Perrilliat, M.d.C., Castañeda-Posadas, C., 2013, Catálogo de plantas fósiles en la Colección Nacional de Paleontología del Instituto de Geología, UNAM, México: Universidad Nacional Autónoma de México, Instituto de Geología, Boletín 119, 109 p.

Person, C.P., 1976, The Middle Jurassic Flora of Oaxaca, Mexico: Austin, University of Texas, $\mathrm{PhD}$ thesis, $200 \mathrm{p}$.

Pindell,J.L., 1985, Alleghanian reconstruction and subsequent evolution of the Gulf of Mexico, Bahamas, and Proto-Caribbean: Tectonics, 4, 1-39.

Pindell, J.L., Kennan, L., 2009, Tectonic evolution of the Gulf of Mexico, Caribbean, and northern South America in the mantle reference frame: An update: Geological Society of London Special Publication, 328, $1-55$.

Ramos-Leal, J.A., 1989, Estratigrafía y evolución Paleoambiental del área de San Juan Ixcaquixtla, Edo. de Puebla: Mexico D.F., Universidad Nacional Autónoma de México, Bachelor's thesis, 70 p. 
Rojas-Chávez, C., 2010, Taxonomía de Dicksoniaceae, Gleicheniaceae y Matoniaceae (Filicales) del Jurásico en la región Mixteca, México: México D.F., Facultad de Estudios Superiores Zaragoza: Mexico D.F., Universidad Nacional Autónoma de México, Bachelor's thesis, 121 p.

Ross, M.I., Scotese, G.R., 1988, A hierarchical tectonic model of the Gulf of Mexico and Caribbean region: Tectonophysics, 135, 139-168.

Sandoval, J., Westermann, G.E.G., 1986, The Bajocian (Jurassic) ammonite fauna of Oaxaca, Mexico: Journal of Paleontology, 60, 1220-1271.

Silva-Pineda, A., 1984, Revisión taxonómica y tipificación de las plantas jurásicas colectadas y estudiadas por Wieland (1914) en la región de El Consuelo, Oaxaca: Paleontología Mexicana, 49, 1-103.
Velasco-de León, M.P., Ortiz-Martínez, E.L., Silva-Pineda, A., Lozano-Carmona, D.E., 2013, Distribución y ambientes de las gimnospermas fósiles del Terreno Mixteco: Paleontología Mexicana, 63, 122-143.

Velasco-de León M. P., Lozano G.D.E., Flores B. M. A., Martínez P.O.D., Silva-Pineda A., 2014, Two new species of Ginkgoales from the Middle Jurassic of Mexico: Historical Biology an International Journal of Paleobiology, 27, 366-373.

Verde-Ramírez, M.A., 2016, Relación entre la tectónica y sedimentación del Jurásico, Santo Domingo Tianguistengo, Oaxaca: Mexico D.F., Instituto de Geología, Universidad Nacional Autónoma de México, Master's thesis, $70 \mathrm{p}$.

Wieland, G.R., 1914, La flora liásica de la Mixteca Alta: Boletín del Instituto Geológico de México, 31, 1-165. 